\title{
No Local Birth Sex Ratio Changes following the August 2019 Shootings in Montgomery County, Ohio, and in El Paso County, Texas
}

\author{
Victor Grech ${ }^{a}$ Hagen Scherb ${ }^{b}$

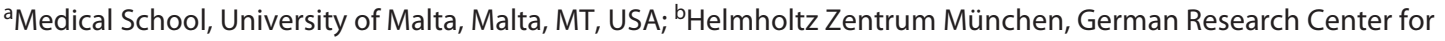 \\ Environmental Health, Neuherberg, Germany
}

\section{Highlights of the Study}

- Violent events may decrease the sex ratio at birth 3-5 months later.

- This is due to spontaneous abortion of frailer male fetuses.

- No such losses occurred following 2 US shootings in 2019.

- This may be due to a smaller effect as these were local events or due to US populations becoming accustomed to such shootings.

\section{Keywords \\ Ecological study $\cdot$ Gender proportions $\cdot$ Terrorist attacks}

\begin{abstract}
Objective: In humans, males are born slightly in excess of females. Many factors have been shown to affect this ratio, including stressful events such as terrorist attacks. Two shootings occurred in early August 2019 in the Oregon District in Dayton, Montgomery County, Ohio, and in El Paso County, Texas, in the USA. This study was carried out in order to identify whether there were any effects on sex ratio at birth at the state or county level 3-5 months later. Subject and Methods: Births by sex, month of birth (2015-2019), and county were obtained for Ohio and Texas from the website of the Centers for Disease Control and Prevention. Ordinary linear logistic regression was used to assess the time trend in the probability of boys and to investigate changes in the trend functions. Poisson regression (SAS GENMOD) and linear logistic regression using SAS procedure LOGISTIC was applied. Results: This study analyzed 2,623,714 live births,
\end{abstract}

1,939,938 in Texas (sex odds [SO] 1.044) and 683,776 in Ohio (SO 1.045). The only significant effect noted was seasonality (month) at the state level. Conclusion: It has been postulated that male fetal loss in pregnant women during stressful periods may occur in accordance with the Trivers-Willard hypothesis. Several studies have found significant effects after terrorist attacks in the USA (as well as in other countries), but this study did not reveal such effects. This may be due to several reasons including underpowered datasets and the possibility that populations may be becoming relatively immured to these events.

(C) 2021 The Author(s).

Published by S. Karger AG, Basel

\section{Introduction}

In humans, males are born slightly in excess of females [1]. However, many factors have been implicated as influencing this ratio [2-4]. For example, stress has been shown to acutely and transiently result in a drop in this ratio, including after terrorist attacks. This was shown after sev-
(C) 2021 The Author(s)

Published by S. Karger AG, Basel

This is an Open Access article licensed under the Creative Commons Attribution-NonCommercial-4.0 International License (CC BY-NC) (http://www.karger.com/Services/OpenAccessLicense), applicable to the online version of the article only. Usage and distribution for commercial purposes requires written permission.
Correspondence to:

Victor Grech, victor.e.grech@gov.mt 
eral events including, for example, in the USA after the September 11 attacks [5]. These changes in sex ratio may be due to stress-induced maternal hormonal variations (such as a rise in follicular testosterone) with a loss of male fetuses as these are more vulnerable [6,7]. This has been noted classically, for example, after short wars or disasters with fewer males than usual being born 6 months later, while at the end of a long war, more males are born [6].

Several other violent events have since been shown to result in similar effects, as evidenced by a meta-analysis that pooled the 2011 Anders Breivik Norway attacks, the 2012 Sandy Hook Elementary School shooting, the September 11, 2001, attacks, and the 2004 Madrid and 2005 London bombings [8]. It has been shown that such events may result in a transient decline in the sex ratio at birth 3-5 months later, due to an excess of male losses in ongoing pregnancies [9].

Two shootings occurred in early August 2019 in the USA. On August 4, a lone shooter killed 9 people and injured 17 others in the Oregon District of Dayton, Montgomery County, Ohio. On August 3, another lone shooter killed 23 people and injured 23 others in El Paso County, Texas. The only extant meta-analysis on this subject noted that lone wolf events were likelier to generate significant effects on the sex ratio. The current study was carried out in order to identify whether there were any sex ratio effects at birth at the state or county level 3-5 months after these 2 events, i.e., October-December 2019.

\section{Subjects and Methods}

Births by sex, month of birth (for the years 2015-2019), and county were obtained for Ohio and Texas from the website of the Centers for Disease Control and Prevention (CDC Wonder: https://wonder.cdc.gov/natality.html). Ordinary linear logistic regression was used to assess the time trend in the probability of boys among live births $(m+f)$ and to investigate whether there were significant changes (drops or jumps) in the trend functions. This involved considering the male proportion $(\mathrm{pm})$ among all male $(\mathrm{m})$ and female ( $\mathrm{f}$ ) births: $\mathrm{pm}=\mathrm{m} /(\mathrm{m}+\mathrm{f})$. Pertinent parameters in this context are the sex odds $(\mathrm{SO})=\mathrm{pm} /(1-\mathrm{pm})=\mathrm{m} / \mathrm{f}$ and the sex odds ratio (SOR), which is the ratio of 2 sex odds of interest, e.g., the sex odds in exposed populations divided by the sex odds in nonexposed populations. The required binomial distributional assumption, possible heterogeneity, and autocorrelation issues have been previously considered in detail $[10,11]$. For trend analyses of birth counts and sex odds, Poisson regression (SAS GENMOD) and linear logistic regression using SAS procedure LOGISTIC was applied. Figures were produced with SAS procedure SGPLOT. Software employed was MS-Excel-365 (2016), R 3.5.1, Wolfram MATHEMATICA 11.3, and mostly SAS/STAT software 9.4 (SAS Institute Inc.: SAS/STAT User's Guide, Cary NC: SAS Institute Inc., 2014).

\section{Results}

This study analyzed 2,623,714 live births, 1,939,938 in Texas (SO 1.044) and 683,776 in Ohio (SO 1.045). Totals and $\mathrm{SO}$ are shown in Table 1. Testing for SO fluctuations in October-December 2019 adjusted for time trend, seasonality (month), location (state or county), and location by dip interaction was carried out employing Wald $\chi^{2}$ tests within the framework of logistic regression. The main parameters tested were the hypothetical sex ratio level shifts in October-December 2019. The logistic regression models for performing these tests were adjusted for time, seasonality (month), location (state or county), period, and location $\times$ period interactions. A typical sample model equation in symbolic SAS notation for these purposes employing dummy variables defined in the class statement is as follows:

\begin{tabular}{|ll|}
\hline Proc logistic & Data $=$ data \\
Class & Month location dip \\
Model & Male/(male + female $)=$ time month location $\mid$ dip $/$ \\
& scale $=d$ \\
\hline
\end{tabular}

The vertical bar (|) between 2 variables denotes the inclusion of both their main effects and their interaction. Results are shown in Table 2 . The only significant effect is seasonality (month) at the state level. Figure 1 shows insignificant dips in October-December 2019 at the state level and statistically even weaker fluctuations at the county level, with and without adjusting for month. Poisson regression was not applied in this context as it was considered inappropriate as no analysis was considered or evaluated for trends in the absolute sex-specific counts.

\section{Discussion}

It has been postulated that male fetal loss in pregnant women during stressful periods may occur in accordance with the Trivers-Willard hypothesis. This avers that under good conditions, parents have more male offspring, and when conditions are poor, parents have less male offspring. This confers an evolutionary advantage in that in polygynous species (such as humans), males have greater mating opportunities and a higher chance of passing on their genes than females who are constrained by gestation and lactation. In poor conditions, male fetuses may not survive to term, and if they do, males born in poor conditions will not be able to compete well with more robust males. Pregnant females may therefore have developed the ability to spon- 
Table 1. Births in Ohio and Texas 2015-2019 by sex

\begin{tabular}{|c|c|c|c|c|c|}
\hline State & Year & Male & Female & Total & SO \\
\hline Ohio & 2015 & 71,286 & 67,978 & 139,264 & 1.049 \\
\hline Ohio & 2016 & 70,636 & 67,449 & 138,085 & 1.047 \\
\hline Ohio & 2017 & 69,975 & 66,857 & 136,832 & 1.047 \\
\hline Ohio & 2018 & 68,933 & 66,201 & 135,134 & 1.041 \\
\hline Ohio & 2019 & 68,608 & 65,853 & 134,461 & 1.042 \\
\hline Total & & 349,438 & 334,338 & 683,776 & 1.045 \\
\hline Texas & 2015 & 206,066 & 197,552 & 403,618 & 1.043 \\
\hline Texas & 2016 & 203,339 & 194,708 & 398,047 & 1.044 \\
\hline Texas & 2017 & 194,958 & 187,092 & 382,050 & 1.042 \\
\hline Texas & 2018 & 193,321 & 185,303 & 378,624 & 1.043 \\
\hline Texas & 2019 & 192,987 & 184,612 & 377,599 & 1.045 \\
\hline Total & & 990,671 & 949,267 & $1,939,938$ & 1.044 \\
\hline County (state) & Year & Male & Female & Total & SO \\
\hline Montgomery $(\mathrm{OH})$ & 2015 & 3,439 & 3,220 & 6,659 & 1.068 \\
\hline Montgomery $(\mathrm{OH})$ & 2016 & 3,365 & 3,266 & 6,631 & 1.030 \\
\hline Montgomery $(\mathrm{OH})$ & 2017 & 3,475 & 3,255 & 6,730 & 1.068 \\
\hline Montgomery $(\mathrm{OH})$ & 2018 & 3,380 & 3,100 & 6,480 & 1.090 \\
\hline Montgomery $(\mathrm{OH})$ & 2019 & 3,228 & 3,167 & 6,395 & 1.019 \\
\hline Total & & 16,887 & 16,008 & 32,895 & 1.055 \\
\hline El Paso (TX) & 2015 & 6,860 & 6,661 & 13,521 & 1.030 \\
\hline El Paso (TX) & 2016 & 6,716 & 6,357 & 13,073 & 1.056 \\
\hline El Paso (TX) & 2017 & 6,118 & 5,895 & 12,013 & 1.038 \\
\hline El Paso (TX) & 2018 & 5,952 & 5,769 & 11,721 & 1.032 \\
\hline El Paso (TX) & 2019 & 5,877 & 5,760 & 11,637 & 1.020 \\
\hline Total & & 31,523 & 30,442 & 61,965 & 1.036 \\
\hline
\end{tabular}

SO, sex odds.

taneously abort male fetuses in poor conditions which affords them the possibility to become pregnant again: if a female ensues, she can still become pregnant while if a male ensues and conditions have improved, this once again provides better mating opportunities [12].

This is supported by several studies including the finding of increased spontaneous abortion following traumatic events, presumably of frailer male fetuses, who also have diminished life expectancy having not been "culled" in utero $[9,13-15]$. Furthermore, many types of traumatic events have been shown to reduce the sex ratio at birth including famine [16], natural events such as volcanic eruptions [17], political turmoil [18], tragic deaths of important personages [19], and recessions [20, 21].

This study did not find any significant effects of these 2 violent events on the birth sex ratio, and this is not the
Table 2. Tests for sex ratio dips

\begin{tabular}{llll}
\hline Effect & DF & Wald $x^{2}$ & $\operatorname{Pr}>X^{2}$ \\
\hline $\begin{array}{l}\text { Joint tests for model parameters } \\
\text { State level }\end{array}$ & & \\
$\quad$ Month* & 11 & 24.49 & 0.0108 \\
$\quad$ Dip Oct-Dec 2019 & 1 & 0.26 & 0.6078 \\
$\quad$ State & 1 & 0.41 & 0.5196 \\
$\quad$ State*dip Oct-Dec 2019 & 1 & 0.46 & 0.4988 \\
County level & & & \\
$\quad$ Month & 11 & 7.81 & 0.7300 \\
$\quad$ Dip Oct-Dec 2019 & 1 & 0.63 & 0.4283 \\
$\quad$ County & 1 & 0.98 & 0.3221 \\
County dip Oct-Dec 2019 & 1 & 1.30 & 0.2540 \\
\hline
\end{tabular}

* Denotes $p<0.05$. 


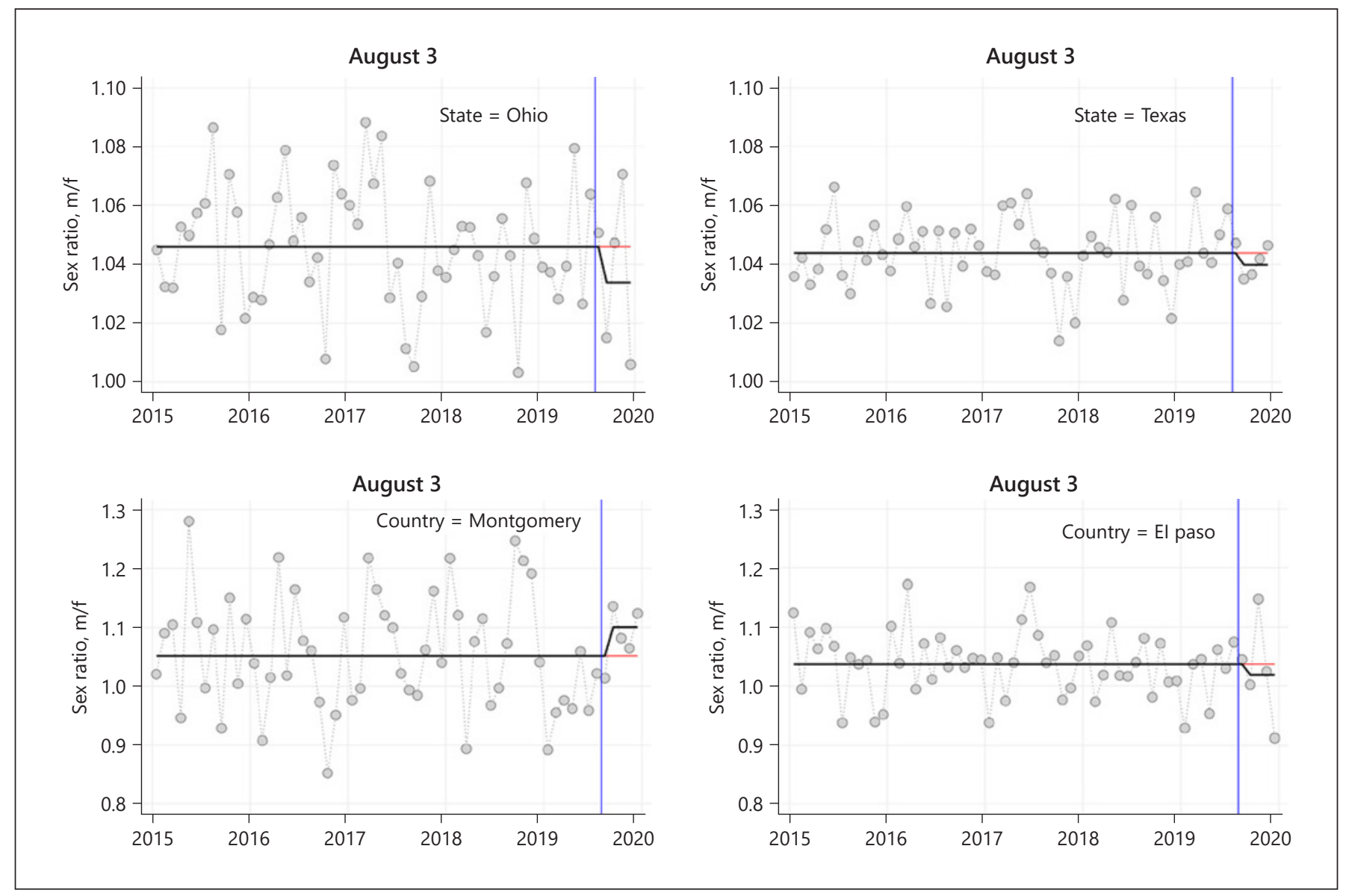

Fig. 1. Sex odds in Oct-Dec 2019 at the state level (top) and county level (bottom).

first negative study of this kind [22]. It has been postulated that a lack of effect could be due to several factors including the perceived magnitude of the event and that such studies may have been relatively underpowered [23, $24]$. It has also been suggested that a more detailed analysis might find such an effect, such as the disaggregated data (e.g., by county) [21]. This study failed to find effects even at the county level; however, when data are disaggregated to this level, statistical power naturally declines.

In the USA, state-wide effects have been noted following not only the September 11 attacks [3] but also the Los Angeles Riots (the Rodney King affair) of 1992 and the Sandy Hook shootings of 2012 which affected the states of California and Connecticut, respectively [22]. These findings were not replicated in our study, and while it is possible that earlier studies yielded a decline in the sex ratio at birth as a result of false-positive findings, this is unlikely as many of these studies were highly powered and some involved millions of births.

\section{Conclusion}

The lack of effect noted in this study may be due to several reasons including not only underpowered datasets but also due to populations becoming relatively immured to these events.

\section{Statement of Ethics}

This study was carried out on an anonymous dataset - no ethics or data protection applications were required.

\section{Conflict of Interest Statement}

The authors have no conflicts of interest to declare. 


\section{Funding Sources}

No funding was sought for this study.

\section{Author Contributions}

Both authors contributed equally to this study.

\section{References}

1 Grech V, Mamo J. What is the sex ratio at birth? Early Hum Dev. 2020 Jan; 140:104858.

2 West L, Grech V. A systematic search of the factors that influence the sex ratio at birth. Early Hum Dev. 2020 Jan;140:104865.

3 Jacobsen R, Møller H, Mouritsen A. Natural variation in the human sex ratio. Hum Reprod. 1999 Dec;14(12):3120-5.

4 Chahnazarian A. Determinants of the sex ratio at birth: review of recent literature. Soc Biol. 1988;35(3-4):214-35.

5 Catalano R, Bruckner T, Marks AR, Eskenazi B. Exogenous shocks to the human sex ratio: the case of September 11, 2001 in New York City. Hum Reprod. 2006 Dec;21(12):312731.

6 Grant VJ. Wartime sex ratios: stress, male vulnerability and the interpretation of atypical sex ratio data. J Evol Psychol. 2009 Dec 1;7(4): 251-62.

7 James WH, Grech V. Can sex ratios at birth be used in the assessment of public health, and in the identification of causes of selected pathologies? Early Hum Dev. 2018 Mar; 118:1521.

8 Masukume G, O’Neill SM, Khashan AS, Kenny LC, Grech V. The terrorist attacks and the human live birth sex ratio: a systematic review and meta-analysis. Acta Medica. 2017;60(2): 59-65.

9 Bruckner T, Catalano R. The sex ratio and age-specific male mortality: evidence for culling in utero. Am J Hum Biol. 2007 Nov-Dec; 19(6):763-73.
10 Scherb H, Voigt K. The human sex odds at birth after the atmospheric atomic bomb tests, after Chernobyl, and in the vicinity of nuclear facilities. Environ Sci Pollut Res Int. 2011 Jun;18(5):697-707.

11 Scherb H, Voigt K. The human sex odds at birth after the atmospheric atomic bomb tests, after Chernobyl, and in the vicinity of nuclear facilities: comment. Environ Sci Pollut Res Int. 2012;19(4):1335-40.

12 Trivers RL, Willard DE. Natural selection of parental ability to vary the sex ratio of offspring. Science. 1973 Jan 5;179(4068):90-2.

13 Catalano R, Casey JA, Bruckner TA. A test of oscillation in the human secondary sex ratio. Evol Med Public Health. 2020 Apr 21;2020(1): 225-33.

14 Catalano R, Ahern J, Bruckner T, Anderson E Saxton K. Gender-specific selection in utero among contemporary human birth cohorts. Paediatr Perinat Epidemiol. 2009 May;23(3): 273-8.

15 Catalano R, Bruckner T. Secondary sex ratios and male lifespan: damaged or culled cohorts. Proc Natl Acad Sci U S A. 2006 Jan 31;103(5): 1639-43.

16 Song S. Does famine influence sex ratio at birth? Evidence from the 1959-1961 great leap forward famine in China. Proc Biol Sci. 2012 Jul 22;279(1739):2883-90.
17 Grech V, Borg T. Seasonality of sex ratio at births in Iceland and effects of the 2010 Eyjafjallajökull volcanic eruption. Acta Paediatr. 2016 Nov;105(11):1369-70.

18 Grech V. The secondary sex ratio at birth was depressed in Quebec by the sovereignty referendums. J Obstet Gynaecol Can. 2015 May; 37(5):405-11.

19 Grech V. Historic royal events and the male to female ratio at birth in the United Kingdom. Eur J Obstet Gynecol Reprod Biol. 2015 Aug; 191:57-61.

20 Catalano RA. Sex ratios in the two Germanies: a test of the economic stress hypothesis. Hum Reprod. 2003 Sep;18(9):1972-5.

21 Grech V. The Great Recession of 2007 in the United States and the male: female ratio at birth. J Turk Ger Gynecol Assoc. 2015 Jun 1; 16(2):70-3.

22 Grech V. The sex ratio at birth, the 10/17 Las Vegas shooting and the 01/18 Hawaii false missile alert. Early Hum Dev. 2020 Apr; 143: 104966.

23 Santos-Lozada AR. A cautionary tale for measuring the effect of the 10/17 Las Vegas shooting and the 01/18 Hawaii false missile alert. Early Hum Dev. 2021 Feb;153:105302.

24 Grech V. Terrorist attacks and the male-tofemale ratio at birth: the troubles in Northern Ireland, the Rodney King riots, and the Breivik and Sandy Hook shootings. Early Hum Dev. 2015 Dec;91(12):837-40. 